\title{
Duration of Immunity After Rubella Vaccination: A Long-Term Study in Switzerland
}

\author{
Max Just, Vroni Just, Rosemarie Berger, \\ Felix Burkhardt, and Ueli Schilt
}

\author{
From the Children's Hospital, Department of Microbiology, \\ University of Basel, Basel; and the Institute for Hygiene and \\ Medical Microbiology, University of Berne, \\ Berne, Switzerland
}

\begin{abstract}
In Switzerland 319 of 594 young women seronegative for rubella antibody vaccinated at 15-25 years of age against rubella with the Cendehill vaccine strain were retested 15 years later with three tests (hemagglutination inhibition, enzyme-linked immunosorbent assay, and a neutralization technique) for the presence of rubella antibodies. For 307 women rubella antibodies were still detectable by all three techniques. For nine women rubella antibodies were demonstrable by only one or two tests. Only three vaccinees were seronegative by all three tests. These three women also showed no booster response after challenge with the vaccine strain. The high percentage of women with persistent rubella antibodies 15 years after vaccination might be explained in part by the presence of subclinical reinfections due to a wild rubella virus.
\end{abstract}

In Switzerland, as in other European countries, immunization against rubella has been particularly advocated for girls while they are still in school so as to directly protect the population at risk. For Europeans one of the reasons for not immunizing infants, as has been the practice in the United States, was the uncertain persistence of the rubella vaccine-induced immunity. Studies evaluating levels of rubella antibodies $\geqslant 12$ years after rubella vaccination are either lacking or are based on small numbers of vaccinees. In Basel, rubella immunizations were already started on an experimental basis in the fall of 1967 on a fairly large scale.

In 1983, we had the opportunity to test $>\mathbf{3 0 0}$ rubella antibody-seronegative vaccinees for levels of various humoral antibodies (hemagglutination inhibition [HAI], ELISA, neutralization) 15 years after immunization. The few women without antibodies or with doubtful immunity were challenged with the Cendehill strain of vaccine virus.

\section{Study Program and Methods}

Vaccinees. Testing of schoolgirls while they are still in school (at the age of 14-19 years) for rubella immunity was started in Basel in the fall of 1967. Besides schoolgirls, women training to be nurses and

This study was supported in part by grant no. $3.811-0.83$ from the Swiss Nationalfonds.

Please address requests for reprints to Dr. Max Just, University Children's Hospital, Römergasse 8, CH-4005 Basel, Switzerland. kindergarten teachers were also screened $[1,2]$. For economic reasons, in the spring of 1969 , pretesting for the presence of rubella antibody before immunization was discontinued in the schools.

Between the fall of 1967 and the spring of 1969 , $>600$ rubella antibody-seronegative young women were identified. Most of them were immunized with the Cendehill vaccine. For most vaccinees a second blood sample - already taken four weeks after the immunization with the Cendehill vaccine - was available. Of the vaccine-induced seroconverters, 594 were included in our evaluation program.

In the late summer and fall of 1983 ( 15 years after the Cendehill vaccination), blood samples were taken from $319(54 \%)$ of the 594 vaccinees. None of the vaccinees had a history of clinical rubella or rubellalike illness or of a second rubella vaccination in the period between the vaccination and the tests done 15 years later.

Rubella vaccines. In the 1967-1969 period, only Cendehill vaccine $[3,4]$ produced by Smith KlineRIT (Rixensart, Belgium) was available. The same Cendehill vaccine strain was used for the challenge studies.

Challenge study. The women lacking immunity or having doubtful immunity were challenged by im injection of the Cendehill vaccine strain. Blood was drawn from these women just before challenge and one, two, and six weeks later.

Evaluation of the rate of natural reinfection. As already mentioned, the first antibody control test in the vaccinees was done four weeks after immunization. In 1967-1968 we did not yet know that the peak 
serum antibody level after Cendehill vaccination is reached only after an interval of six to 12 weeks [5]. Thus we cannot directly compare the postimmunization antibody titers with those measured in the blood samples taken 15 years later. From a portion of our vaccinees, several serum samples were received during the 15 -year period. For all vaccinees for whom at least six serum samples (not including the prevaccination and the first postvaccination samples) were available, frozen $(-20 \mathrm{C})$ sera were thawed, and all samples-including the 1983 serum-were simultaneously tested by the HAI method.

Rubella antibody tests. In the 1967-1969 period, preimmunization and first postimmunization blood samples were evaluated only by the HAI technique. But when the first postimmunization serum was tested, the preimmunization sample was always simultaneously reevaluated. All serum samples taken in 1983 were examined by the HAI and ELISA techniques. Most of these sera (especially those with relatively low titers) were also evaluated by the neutralization method. All the sera of the challenge study were checked not only for total or IgG antibodies but also for specific IgM antibodies.

Tests for total and IgG rubella antibodies. HAI tests were carried out as described by Herrmann et al. [6]. Nonspecific inhibitors were removed with heparin and $\mathrm{MnCl}$. Pigeon erythrocytes were used within one to two days of collection.

The ELISA used for detection of IgG rubella antibodies was performed with the commercial Rubazyme diagnostic kit (Abbott Laboratories, North Chicago, Ill.).

Neutralization tests were carried out as reported by Herrmann et al. [6] with the following modifications. Vero cells were grown in glass tubes for four days. Rubella virus $(0.5 \mathrm{ml})$ strain 8238 [7] at a dilution of $50 \mathrm{TCID}_{50} / \mathrm{ml}$ was mixed with $0.5 \mathrm{ml}$ of diluted serum - TC 199 medium being the diluent in both cases - and incubated for $1 \mathrm{hr}$ at $37 \mathrm{C}$. The above serum-virus mixture $(0.2 \mathrm{ml})$ was inoculated in the glass tubes with the Vero cells. The tubes were incubated for seven days at $37 \mathrm{C}$. Viral multiplication or its inhibition by serum was assayed by indirect immunofluorescence as described by Schilt [7].

Tests for IgM rubella antibodies. In the HAI test, the serum to be tested was first separated by gel filtration on agarose, as described by Bürgin-Wolff et al. [8]. The IgM fraction was tested in the usual HAI setup. In the ELISA, the presence of IgM antibodies was determined with the Rubazyme-M diagnos- tic kit produced commercially by Abbott. The presence of IgM antibodies was also determined by the M-antibody capture RIA (MACRIA) method of Mortimer et al. [9].

For comparison of titers an international control serum, made available to us by Dr. P. S. Gardner (Colindale, England), was included in our test series.

\section{Results}

Long-term evaluation of vaccine-induced antibodies. Of the 319 women tested 15 years after immunization with the Cendehill vaccine, 307 were still seropositive for antibodies by all three tests. Three $(1 \%)$ were seronegative by all three tests. For nine women we consider immunity doubtful because one or two of the tests gave a negative result.

Challenge study. The three seronegative women (results of all antibody tests were negative) and seven of the women with doubtful immunity (results of one or two of the tests were negative) were challenged with the Cendehill vaccine strain. Women with proven immunity (results of all three tests were still positive 15 years after the vaccination) were not challenged.

Table 1 summarizes the IgG and IgM antibody responses of the women after challenge. All three seronegative women showed a "primary vaccine reaction": no antibodies were found until more than seven days after challenge. IgM antibodies were detectable after challenge by all three tests. For one vaccinee, IgM rubella antibodies were found after two weeks, and in two vaccinees, in the third blood sample after challenge. All seven women with doubtful immunity showed some kind of a "memory reaction" after challenge. In none of these seven were rubella IgM antibodies detectable by any test, but all women showed some increase in the rubella IgG antibody titer.

Subclinical reinfections. For 94 of the vaccinees, at least six serum samples were collected during the 15 -year period. For nine of these women, a significant increase in antibody levels was observed, a finding which suggests that for at least $10 \%$ of the vaccinees a subclinical reinfection must have occurred.

\section{Discussion}

All studies on the persistence of vaccine-induced rubella antibodies have shown a high percentage of vaccinees with persistence of immunity as measured 
Table 1. Antibody response of women with negative or doubtful immunity to rubella 15 years after vaccination on challenge with Cendehill vaccine strain.

\begin{tabular}{|c|c|c|c|c|c|c|}
\hline \multirow{3}{*}{$\begin{array}{l}\text { Category of } \\
\text { immunity results } \\
\text { (no. of women), } \\
\text { no. of days } \\
\text { after challenge }\end{array}$} & \multicolumn{6}{|c|}{$\begin{array}{l}\text { No. of women positive for indicated type } \\
\text { of rubella antibody by test }\end{array}$} \\
\hline & \multicolumn{2}{|c|}{ HAI* } & \multicolumn{2}{|c|}{ ELISA $^{\dagger}$} & \multirow{2}{*}{$\frac{\text { MACRIA } \ddagger}{\operatorname{IgM}}$} & $\begin{array}{l}\text { Neutral- } \\
\text { izationll }\end{array}$ \\
\hline & All & IgM & $\operatorname{IgG}$ & $\operatorname{Ig} M$ & & All \\
\hline \multicolumn{7}{|l|}{ Negative (3) } \\
\hline 0 & 0 & 0 & 0 & 0 & 0 & 0 \\
\hline 7 & 0 & 0 & 0 & 0 & 0 & 0 \\
\hline 14 & 1 & 2 & 0 & 1 & 1 & 1 \\
\hline 42 & 3 & ND & 3 & $2 \S$ & $2 \S$ & 3 \\
\hline \multicolumn{7}{|l|}{ Doubtful (7) } \\
\hline 0 & 4 & 0 & 4 & 0 & 0 & 2 \\
\hline 7 & 4 & 0 & 4 & 0 & 0 & 5 \\
\hline 14 & 7 & 0 & 7 & 0 & 0 & 6 \\
\hline 42 & 7 & ND & 7 & 0 & 0 & 7 \\
\hline
\end{tabular}

NOTE. Negative category denotes absence of rubella antibodies by three tests (HAI, ELISA, neutralization) before challenge. Doubtful category denotes presence of rubella antibodies by one or two of these three tests before challenge. Abbreviations: $\mathrm{HAI}=$ hemagglutination inhibition; MACRIA $=$ M-antibody capture RIA; ND = not determined.

* Positive result indicated by the presence of $\geqslant 5$ IU of rubella antibodies $/ \mathrm{ml}$ or a titer of $\geqslant 1: 8$.

$\dagger$ Positive result indicated by the presence of $\geqslant 10$ IU of rubella antibodies $/ \mathrm{ml}$

$¥$ Positive result indicated by a binding ratio of test to negative serum of $>2$ [9].

\| Positive result indicated by the presence of $\geqslant 5$ IU of rubella antibodies $/ \mathrm{ml}$ or by a titer of $\geqslant 1: 2$.

$\S$ The woman who was IgM-positive on day 14 was IgMnegative at day 42 .

by tests of humoral antibody (e.g., [10-12]). But we were surprised that in our long-term study only three $(1 \%)$ of 319 women had lost all rubella antibodies 15 years after immunization with Cendehill vaccine. For $307(96.2 \%)$ of the 319 women, rubella antibodies were still detectable by all three test methods. These surprising results reflect either methodologic errors, the way in which the sample was collected, or a unique epidemiologic situation. Methodologic errors can be excluded, chiefly because the results were similar when different tests were used. Fifteen years after the vaccination we could trace only $54 \%$ of the original study group. However, it is not surprising that the percentage is this low because most vaccinees had changed not only their address but also their family name by marriage. In Switzerland no official proposals for rubella revaccinations have been published. Therefore, it is unlikely that a sig- nificant number of our vaccinees had received a second rubella immunization. The exact number of rubella cases in Switzerland in the last 15 years is not known. However, a significant decrease in the number of childhood rubella cases has not occurred. It is likely that a portion of our vaccinees had had a subclinical natural rubella infection; in $10 \%$ of our study group, such a reinfection was proved by a significant increase in antibody levels. Because a sufficient number of serum samples from the same individual vaccinee could not be obtained throughout the 15 -year period, the measured reinfection rate of $10 \%$ is the minimal rate of possible reinfections.

The essential result, namely that only $1 \%$ of the vaccinees lost antibody after 15 years, shows that at least under the epidemiologic conditions of the last 15 years, the immunity induced by rubella vaccination - even with the Cendehill vaccine - is a longlasting one.

The epidemiologic situation regarding rubella in Switzerland and in all other European countries is not the same as that in the United States. In Europe, the chance of rubella-vaccinated adults coming into contact with children infected with wild rubella virus is still high. The high percentage of women with persistent rubella immunity 15 years after vaccination could therefore be explained in part by a history of subclinical reinfection.

When a policy of rubella vaccinations for children is enforced in Europe, the risk of subclinical reinfections for vaccinees will decrease. In Germany it is officially recommended that all girls vaccinated against rubella in infancy be revaccinated at the onset of puberty [13]. Whether such general, uncontrolled rubella revaccinations are really needed must be evaluated by testing for long-term persistence of antibodies to rubella in countries with a low incidence of childhood rubella, such as the United States.

\section{References}

1. Just M, Bürgin-Wolff A, Ebner R, Ritzel G. Rötelnimpfung bei jüngeren weiblichen Erwachsenen. Schweiz Med Wochenschr 1968;98:1549-51

2. Just M, Bürgin-Wolff A, Frutiger U, Ritzel G. Probleme der Massenimpfung gegan Röteln. Schweiz Med Wochenschr 1969;953-5

3. Peetermans J, Huygelen C. Attenuation of rubella virus by serial passage in primary rabbit kidney cell cultures. Archiv der gesamten Virusforschung 1967;21:133-43

4. Prinzie A, Huygelen C, Gold J, Farquhar J, McKee J. Ex- 
perimental live attenuated rubella virus vaccine: clinical evaluation of Cendehill strain. Am J Dis Child 1969;118:172-7

5. Andre FE, Florent G, Martin du Pan R. Rubella vaccines and the immunity gap [letter]. Lancet 1979;2:417-8

6. Herrmann KL. Rubella virus. In: Lennette EH, Schmidt NJ, eds. Diagnostic procedures for viral, rickettsial and chlamydial infections. 5th ed. Washington, DC: American Public Health Association, 1979:725-66

7. Schilt U. Rötelnimmunität - Immunfluoreszenztest als rascher und zuverlässiger Alternativtest zum Hämagglutinations Hemmungstest. Disch Med Wochenschr 1979;104:22-4

8. Bürgin-Wolff A, Hernandez R, Just M. Separation of rubella $\operatorname{IgM}, \operatorname{IgA}$, and $\operatorname{IgG}$ antibodies by gel filtration on agarose. Lancet 1971;2:1278-80
9. Mortimer PP, Tedder RS, Hambling MH, Shafi MS, Burkhardt F, Schilt U. Antibody capture radioimmunoassay for anti-rubella lgM. J Hyg (Camb) 1981;86:139-53

10. Herrmann KL, Halstead SB, Wiesbenga NH. Rubella antibody persistence after immunization. JAMA 1982; 247:193-6

11. Zealley H, Edmond E. Rubella screening and immunization of schoolgirls: results six to seven years after vaccination. Br Med J [Clin Res] 1982;284:382-4

12. O'Shea S, Best JM, Banatvala JE, Marshall WC, Dudgeon JA. Rubella vaccination: persistence of antibodies for up to 16 years. Br Med J [Clin Res] 1982;285:253-5

13. Impfkommission. Impfkalender für Kinder. Bundesgesundheitblatt. 1983;26(5):128-31 